\title{
The Indonesian Experience with Two Big Economic Crises
}

\author{
Tulus T. H. Tambunan \\ Center for Industry, SME and Business Competition Studies University of Trisakti, Jakarta, Indonesia \\ E-mail:sjahrir@rad.net.id
}

Received July 13, 2010; revised August 15, 2010; accepted August 18, 2010

\begin{abstract}
This paper aims to examine the Indonesian experience with two big economic crises in the past 12 years, namely the 1997/98 Asian financial crisis and the 2008/09 global economic crisis. The paper is based on secondary data analysis and a review of key literature. It has two main parts. The first part gives a theoretical explanation of the main transmission channels through which the two crises have affected the Indonesian economy. The second part is the empirical part of the paper about the impacts of the crises on such as economic growth, employment, remittances and poverty in Indonesia. One important finding from this study is that the Indonesian economy was much more resilience to the last crisis as compared to the 1997/98 crisis. During this first crisis, Indonesian economic growth was-13 percent and poverty increased significantly; whereas during the second one, Indonesia managed to keep a positive economic growth rate (though declined), and poverty kept declining.
\end{abstract}

Keywords: 2008/09 Crisis, 1997/98 Crisis, Economic Growth, Remittance, Poverty, Unemployment

\section{Introduction}

Indonesia now is much more vulnerable to any economic shocks than, say, 30 years ago, for the following reasons. First, since economic reforms started in the 1980s toward trade, banking, investment, and capital account liberalizations, the Indonesian economy has become more integrated with the world economy. Second, though at a decreasing rate, Indonesia is still dependent on exports of many primary commodities, i.e. mining and agriculture. This means that its economy is still sensitive to any world-price/demand instability for those commodities. Third, Indonesia has become increasingly dependent on imports of a number of food items such as rice, food grains, cereals, wheat, corn, meat, dairy, vegetables and fruits, or even oil. Any increases or instabilities of world prices or the world production failures of these commodities will have big effects on domestic consumption and food security in Indonesia. Fourth, more Indonesian working population, including women, went abroad as migrant workers, and hence livelihoods in many villages in Indonesia have become increasingly dependent on remittances from abroad. Any economic crisis hit the host countries (such as happened in Dubai during its financial crisis in 2009) will hit the Indonesian economy too. Finally, as a huge populated country with increasing income per capita, domestic food consumption is not only high but also keeps increasing. Accelerating output growth in agriculture is therefore a must for Indonesia, and this depends on various factors, including climate, which is an exogenous factor. As Indonesia is located between the Pacific ocean and the Indian ocean in the line of equator, the country is always vulnerable to El Nino/La Nina phenomenon which may cause failures in rice (and other commodities) harvest and therefore will generate a hyperinflation.

Indeed, in the past 12 years, Indonesia has experienced two big economic crises, namely the Asian financial crisis started by mid. 1997 and reached its peak in 1998, and the global economic crisis in 2008 and 2009. This paper aims to examine the Indonesian experiences with these two crises. It addresses two key questions. First, what were the main transmission channels through which the two crises affected the Indonesian economy. Second, was the impact on the Indonesian economy different between the two crises, and if yes, what made the difference?

The paper has three main parts. The first part (Chapter II) gives an theoretical explanation on the main transmission channels through which the two crises have affected the Indonesian economy. The second part (Chapter III) examines empirically the impacts of the two crises on the Indonesian economy focusing on economic growth, export, employment, remittances and 
poverty. The third part (Chapter IV) gives the most likely reasons that made the impact of the 1997/98 crisis different than that of the 2008/09 crisis.

\section{Transmission Channels}

\subsection{The $1997 / 98$ Crisis}

In Indonesia, the 1997/98 Asian financial crisis was triggered by a sudden capital flight from the country which led its national currency, rupiah, to depreciate significantly against the US dollar. The depreciation was soon followed by a national banking crisis and ended up as a national economic crisis. Through the rupiah depreciation and higher interest rate (as the monetary authority's direct response in that time in order to stop capital flight), the crisis hit first middle and high income groups such as current employees in the financial/ banking sector and large scale industries which strongly dependent on credits from bank or other financial institutions and imports. After several months, domestic inflation started to increase, and this accompanied with the increase in unemployment due to many laid off employees in crisis-affected firms than resulted in a significant increase in the poverty rate in 1998.

Thus, for Indonesia, the $1997 / 98$ crisis was initialy a currency crisis. Theoretically, the direct impact of a currency depreciation will be mainly on export and import of the particular country (Figure 1). By assuming other factors constant, export, and hence, production and employment or income in the exporting firms/sectors and in their backward as well as forward linked firms/sectors will increase. This is the export effect of a currency depreciation. On the import side, domestic prices of imported consumption and non-consumption goods will also increase. In the case of non-consumption goods, i.e. raw materials, capital and intermediate goods, components/ spare parts, as a response to higher prices (in national currency) of these imported goods, two scenarios are possible: (1) imports decline and, consequently, total domestic production and employemnt also drop, or (2) imports may stay constant, but it means thus domestic production cost will increase and finally it will result in higher domestic inflation. This is the import effect of a currency depreciation.

Besides the above effects, a national currency depreciation also makes the value in national currency of foreign debts (in foreign currency against which the national currency has depreciated) owned by domestic firms to rise. Many highly foreign indebted domestic firms will face a serious financial crisis. If many of them have to reduce their production or even collapse, domestic total production and employment will then further decline. This can be called as the foreign debt cost effect of a national currency depreciation. ${ }^{1}$

The net result of all effects discussed above on poverty, however, can be postive, or negative, or no effect at all, depending on whether the export (positive) effects are larger, equal to or smaller than the import and foreign debts cost (negative) effects of the rupiah depreciation. The key issue here is whether export will increase when national currency is weakening. It depends at least on two main factors. First, the proportion of imported inputs in the export products, because it will determine to what extent the price competitiveness of the products will increase when national currency depreciates. Second, domestic production capacity of the export goods, which determines to what extent the production will increase when their price competitiveness increases.

So, in this $1997 / 98$ crisis case, the key transmission channels through which the crisis affected the Indonesian economy were changes in export and import volumes and cost (in national currency) of foreign debts. With respect to the impact on poverty, the next transmission channesl were changes in employment/income, and inflation. As export is usually increase (or at least not decline) when national currency depreciates, the most vulnerable group to the crisis is thus on the import side, especially imports of inputs. However, depends on what sectors are most severely affected by higher import costs (in national currency) and their response to the increased import costs: whether they keep the import volume the same as before depreciation and without any labor adjusment (e.g. lay off or less working hour) or reduce the amount of imports and hence production and employment.

\subsection{The 2008/09 Crisis}

The 2008/2009 crisis has been called by many economists as the most serious economic or financial crisis since the great depression in the 1930s. The crisis impacted many countries through various channels, i.e. exports, investment (including foreign direct investment/ FDI), and remittances[1]. However, for Indonesia and many other developing countries, the most important channel was export. Retrenchments mounted in much export- oriented manufacturing firms in these countries, while working time fell along with increased downward pressure

\footnotetext{
${ }^{1}$ Financial conditions of national governments which borrowed a lot of money from abroad will also deteriorate as national currency depreciates. However, in the case of Indonesia, the impact on domestic production and employment was not evident. Even, during the crisis the government could increase its expenditure on fuel, health and education to mitigate the impact of the crisis on the poor. A large part of the increased expenditure was from loans provided by the International Monetary Fund (IMF).
} 


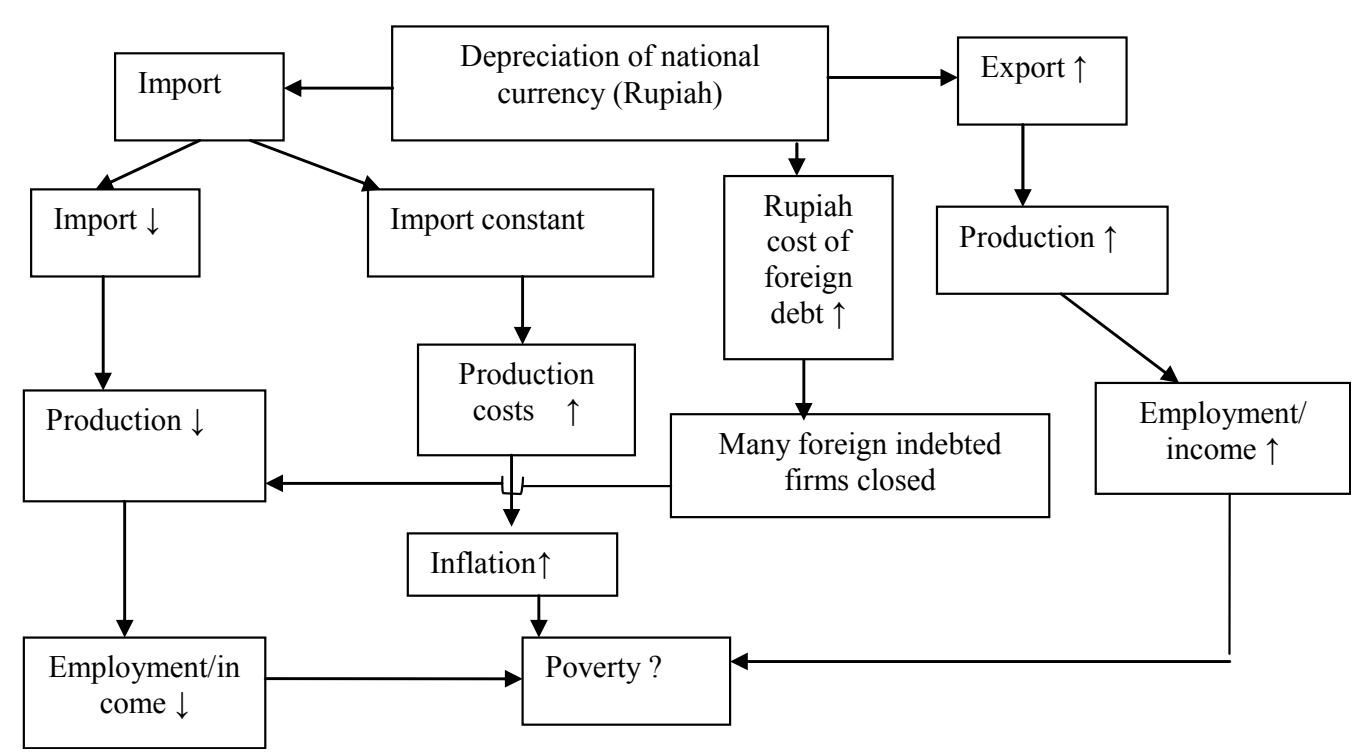

Figure 1. Transmission Channels of the Effects of the 1997/98 Crisis on the Indonesian Economy.

on wages. Also many employees in these firms were laid off and many of them migrated back to rural areas and shifted to informal and vulnerable employment.

As export was the most important transmission channel, therefore, the 2008/09 crisis for Indonesia and most other affected countries was considered primarily as a world demand/export market crisis. Theoretically, as illustrated in Figure 2, this kind of shock will affect the economy of these countries at the first stage through its effects on their domestic export-oriented firms. It leads further to less production and employment in these firms and in other related firms. The employment reduction causes decline in incomes of many households, and it will result further in lower market demands for goods and services and hence production cuts in many industries/sectors. Finally, unemployment and poverty will increase.

In large countries like Indonesia which consists of many islands or regions (i.e. provinces, districts and subdistricts), the impact may vary by region, or even the impact in some regions within the country may more severe than at the national level. For instance, if the decline in average household income in Java island (where most export-oriented manufacturing industries are located) is higher than in the rest of the country, and the proportion of the affected households in Java is significant large, then total income in Java will decline faster than that in the rest of the country.

If remittance inflows to Java also decline from foreign countries also affected by the crisis, then the income in Java will drop further. If remittances to other regions in Indonesia also decline, than the national income or the economic growth rate will decrease. In other words, if only one region in Indonesia was affected by the crisis, and the region's economy is not significant important for the national economy based on gross domestic products (GDP) distribution by region, the effect at the national level my insignificant, even if the impact for that particular region is significant. On the other hand, if Java is the highest Indonesia's GDP contributor, even a small impact of the crisis on Java will produce a serious shock for the national economy.

Thus, depending on: (1) the importance of the affected export commodities in Indonesia's total export; (2) the importance of the commodities and their related sectors (through backward and forward production linkages) in the economy of the regions of origin; (3) the importance of the regions' economy in the Indonesian economy; and (4) the crisis-coping measures taken by the affected firms to mitigate the effect of the crisis, the impact or outcome of the 2008/09 crisis on the Indonesian economy and hence poverty can be large or small. Therefore, in analysing the impact of the crisis on Indonesia's economy and poverty, the key are: (a) what export commodities have been hit by the crisis; (b) in what regions; (c) how are their linkages with the rest of the economy; and (d) what types of workers and their households are mostly affected?

\section{The Impacts}

\subsection{The $1997 / 98$ Crisis}

The 1997/98 crisis hit many countries especially in East and Southeast Asia such as Indonesia, Thailand, Singapore, Malaysia Philippines and South Korea. However, the 


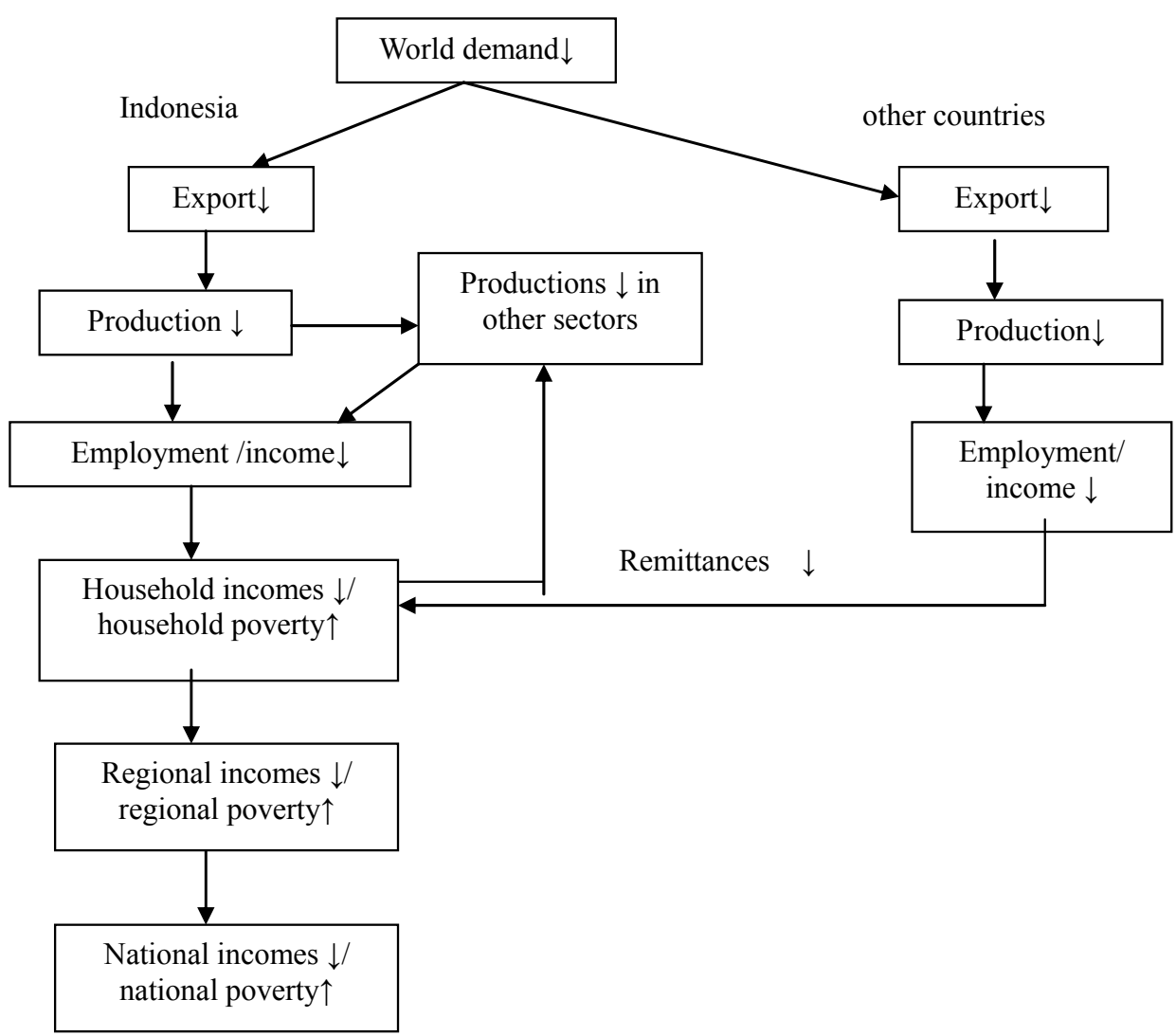

Figure 2. Transmission Channels of the Effects of the 2008/09 Crisis on the Indonesian Economy.

impact varied by country. Indonesia together with South Korea were among the most severely affected ones. The Indonesian economy had plunged into a deep recession in 1998 with overall growth at minus 13.7 per cent (Figure 3). The worst declines were in the construction sector (-39.8 per cent), financial sector (-26.7 per cent), trade, and hotel and restaurant (-18.9 per cent). Other sectors, which had large contractions, were manufacturing $(-12.9$ per cent) and transport and communication $(-12.8$ per cent). Mining and other services sectors experienced a contraction of about 4.5 per cent. The agricultural and utility sectors still experienced positive growth at about 0.2 per cent and 3.7 per cent respectively [2]. The crisis also led to a significant drop in income per capita to drop (Figure 4), and a significant increase in poverty rate (Figure 5). All this evidence may suggest that the rupiah depreciation was more negative rather than positive for the Indonesian economy.

The increase in poverty and the decline in income per capita were consistent with output contractions in many sectors as expained before. There were three main reasons why the rupiah depreciation had caused a serious decline in Indonesia's aggregate output. First, despite the fact that Indonesia has adopted import substitution strategy during the New Order era (1966-1998), Indonesia, especially the manufacturing industrty, has been increasingly dependent on imported capital and intermediate goods, components and spareparts, and some processed raw materials. So, the rupiah depreciation prevented many export-oriented firms from gaining better world price competitiveness, one one hand, while, on the other hand, many domestic market-oriented firms had to close down or to cut their production volume because they could not purchase any more very expensive imports. Second, many firms, expecially conglomerates, during the New Order era had borrowed a lot money from foreign capital markets; mostly were short-term loans. They went bankrupt when rupiah depreciated and many other firms which had business relations with them were also in trouble. Third, the national banking sector was also collapsed. By the end of 199716 commercial banks were closed, and access to credit became very difficult and interest rate increased significantly. This has contributed significantly to output contractions in many sectors in Indonesia.

There is some evidence that the crisis not only increased poverty but also reduced the quality and supply of education and health services. Reference [3] report that the crisis decreased enrolment rates among children aged 8-13 years and increased enrolment rates among 


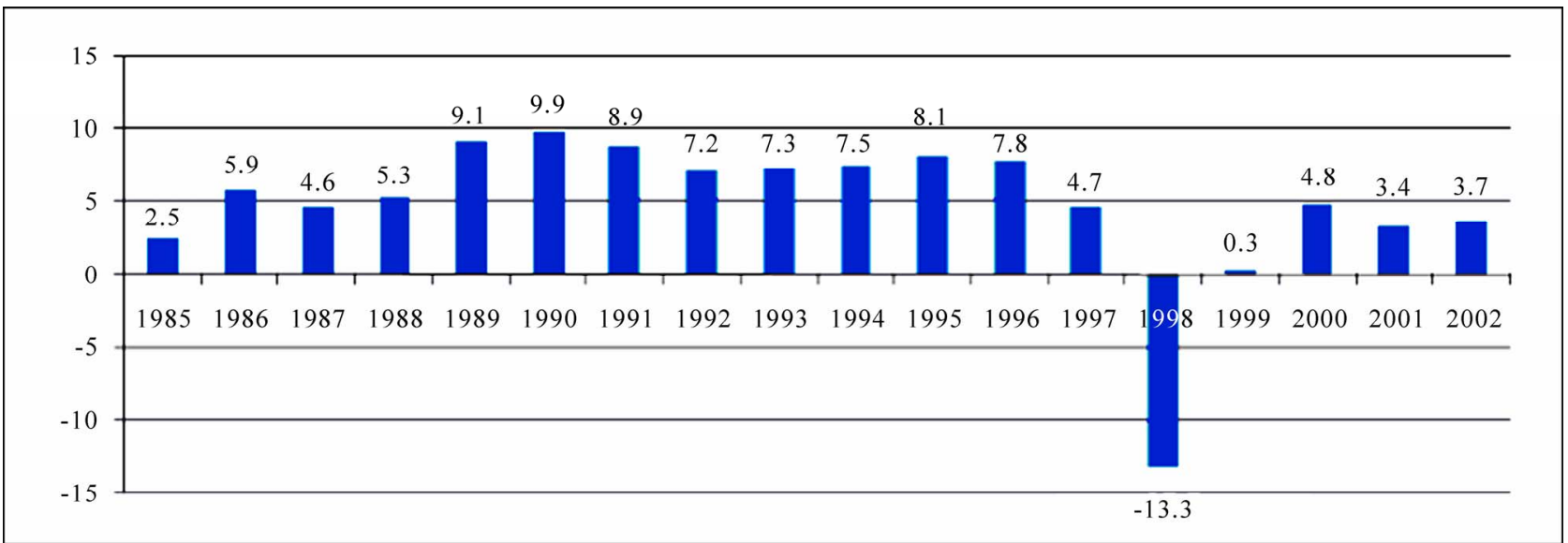

Figure 3. Indonesian GDP Growth rate during the 1997/1998 Crisis. (Source: Statistical Yearbook of Indonesia (various years), Indonesian National Agency of Statistics (BPS) (www.bps.go.id).)

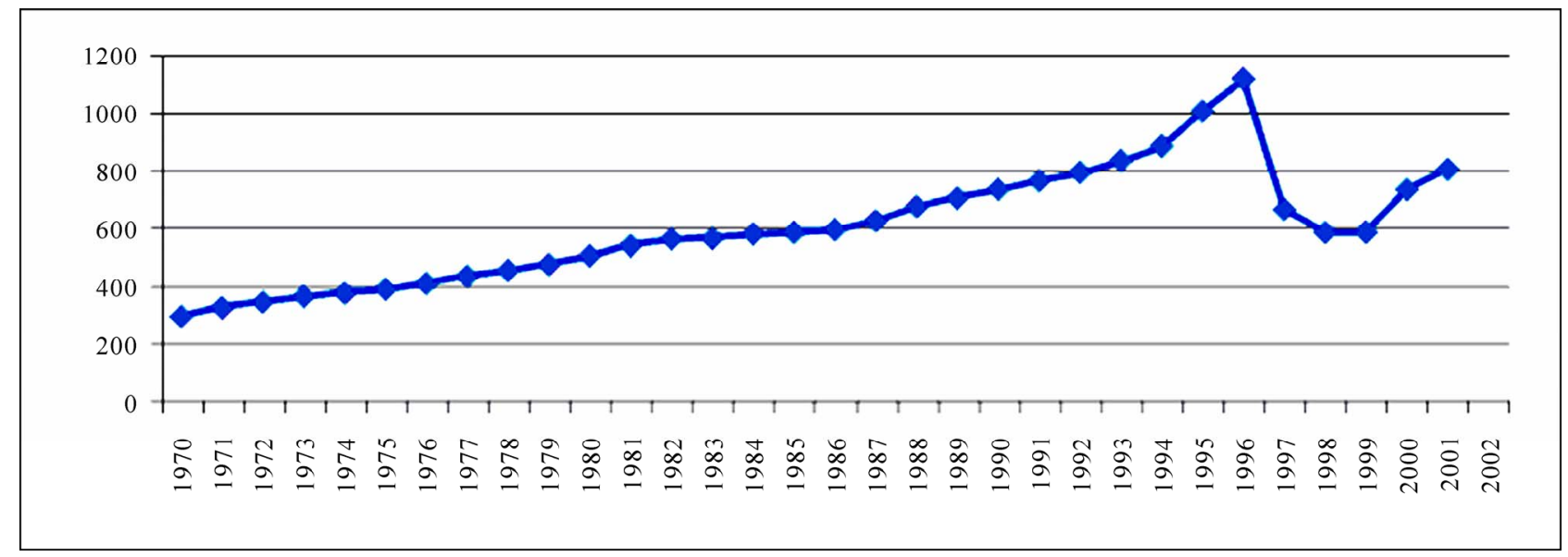

Figure 4. Development of Indonesian Income per Capita during the 1997/98 Crisis Period (US dollar). (Source: Statistical Yearbook of Indonesia (various years), BPS (www.bps.go.id).)

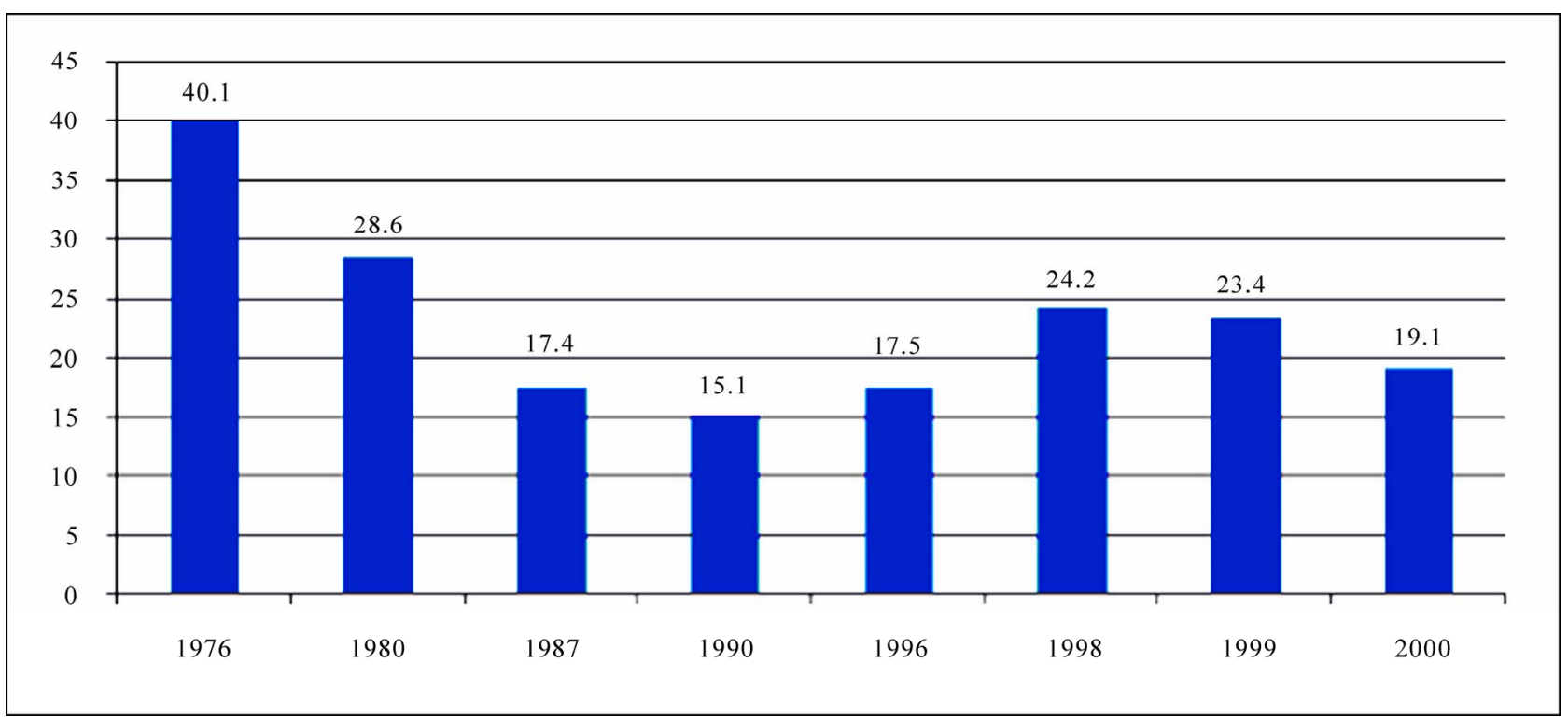

Figure 5. Poverty rate in Indonesia During the 1997/98 Asian Financial Crisis. (Source: BPS,www.bps.go.id) 
children aged 14-19 years, although these changes were small, just one percentage point of enrollment. The impact on school enrolment, however, varied by region, suggesting that different regions in the country may had experienced differently with the crisis. Another important study is a 1999 report issued by the Australian Agency for International Development (AusAID). It shows that the crisis had numerous adverse health impacts in Indonesia, including: (1) declines in, respecttively, personal and government expenditures on primary care. The use of health services for primary care also declined; (2) decline in purchases of medicines; (3) declines in DTP3 immunization rates and polio rates. Vitamin A supplementation also fell. The declines most likely occurred among the poorer populations; (4) decline in the lowest wealth quintile in child visits to health facilities; (5) a halt in the 1990s downward trend in infant mortality; and (7) mortality increases [4].

\subsection{The 2008/09 Crisis}

Up to the end of 2008, countries like Thailand, Malaysia, Singapore, Philippines and Indonesia still shown some resilience towards the crisis. However in the first quarter 2009 , they experienced deteriorating economic performance, except Indonesia (Figure 6). Singapore suffered the most and recorded -8.9 per cent in real GDP growth rate (year-on-year basis) in the first quarter 2009. This was not surprise at all, given the fact that as a tiny economy, Singapore is fully integrated with the global market for goods, services and finance. Consequently, its economy is fully sensitive to any external economic shocks. The country's economy then started to recover with positive growth again in the third quarter. Similarly with Singapore was Thailand which has also been seriously hit by the crisis since the third quarter 2008 and the economy contracted by 7.11 per cent in the first quarter 2009. Thailand achieved again positive growth in the last quarter 2009. Malaysia which experienced a slightly positive growth of around 0.1 per cent in the last quarter 2008, also suffered economic contraction by 6.20 per cent in the first quarter 2009. Meanwhile, Indonesia and the Philippines managed to keep positive growth although at declining rates during the crisis period. In the first quarter 2009, Indonesia achieved 6.2 per cent growth, but in the last quarter it was lower at 5.2 per cent.

While the economy of other countries in the group was deteriorated significantly especially during the first months in 2009, Indonesia has not only positive but also slightly higher GDP growth rates during the second and third quarters 2009. In overall, however, official data (National Agency of Statistics/BPS) show that the growth rate of Indonesian economy was at around 4.5 percent, much lower than the growth rate achieved in 2008 (Figure 7). This may suggest that the Indonesian economy was also affected by the world economic recession in 2008/09, but nevertheless the country was able to keep postive economic growth rates during the crisis period.

Further as shown in Table 1, besides Indonesia, there were other few countries in the region, such as China,



Figure 6. Economic Growth Rate in Selected ASEAN member countries, 2008 and 2009 (\% change year-on-year). (Sources: World Bank database (country indicators) (http://web.worldbank.org/WBSITE EXTERNAL/COUNTRIES/).) 


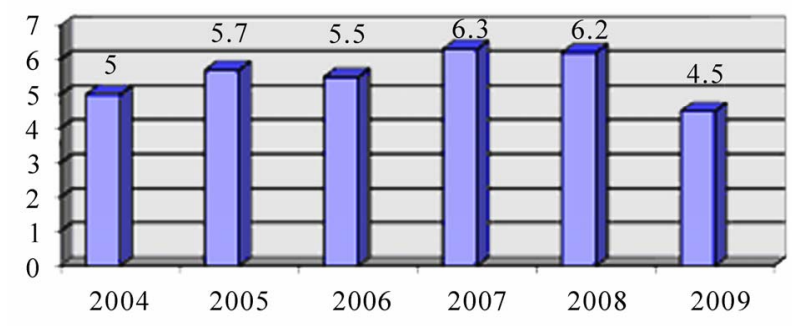

Figure 7. Indonesian Annual Economic Growth 2004-2009 (\%). (Source: Statistical Yearbook of Indonesia (various years), BPS (www.bps.go.id).)

Table 1. Economic growth in the developing world by region, 2007-2010.

\begin{tabular}{lcccc}
\hline & 2007 & 2008 & 2009 & $2010^{*}$ \\
\hline East Asia and Pacific & 11.4 & 8.0 & 6.8 & 8.1 \\
-PRC & 13.0 & 9.0 & 8.4 & 9.0 \\
-Indonesia & 6.3 & 6.2 & 4.5 & 5.6 \\
-Thailand & 4.9 & 2.2 & -2.7 & 3.5 \\
Europe and Central Asia & 7.1 & 4.2 & -6.2 & 2.7 \\
South Asia & 8.5 & 5.7 & 5.7 & 6.9 \\
-India & 9.1 & 6.1 & 6.0 & 7.5 \\
-Pakistan & 5.7 & 2.0 & 3.7 & 3.0 \\
-Bangladesh & 6.4 & 6.2 & 5.9 & 5.5 \\
Latin America and & 5.5 & 3.9 & -2.6 & 3.1 \\
Caribbean & & & & \\
Middle East and North & 5.9 & 4.3 & 2.9 & 3.7 \\
Africa & & 5.5 & 1.1 & 3.8 \\
Sub-Saharan Africa & 6.1 & \\
\hline
\end{tabular}

Note: * forecast by the World Bank. Source: World Bank [5]

India, Pakistan and Banglades which were also managed to mitigate the impact of the crisis on their domestic econmy. Interestingly, the table shows that, within the developing world, countries in Asia and the Pacific region performed much better than those in other parts of the world during the crisis. Of course, many explanations can be thought, including that the variation in the impact of this kind of crisis on domestic economy is strongly related to the degree of integration of the particular country with the world economy. Rapidness and effectiveness of crisis-coping policy measures in the partuicular country may also played an important role.

With respect to remittances, according to ILO [6], the number of Indonesian workers abroad had been on an upward trend until the crisis deepened in mid 2009. Reference [7] provide data which show that the number of Indonesian workers departed overseas increased with
258,000 workers by the end of December 2008 or around 54 percent as compared to the end of September 2008 with 168,000 workers. However, total Indonesian workers went abroad in 2008 were less than in 2007 (Figure 8). However, according to [7] estimation, total remittances inflows from overseas Indonesian workers declined slightly from approximately US $\$ 1.589$ billion in the end of first quarter 2009 from US $\$ 1.61$ billion in December 2008. It is not sure whether the less number of Indonesian overseas workers in 2008 compared to 2007 or the slightly decline in remittances inflows was caused by the crisis?

With respect to the impact of the crisis on employment, according to ADB $[8,9]$, unemployment in many Asian developing countries has risen during the 2008/09 crisis, particularly in the more export-dependent economies of Hong Kong, China; Singapore; and Taipei,China. In Indonesia, the number of workers dismissal and homed in the formal sector has steadily increased during end December 2008 and early December 2009 (Figure 9). While, according to ILO [6] the crisis has prompted a steep fall in the growth of wage employment, which grew about 1.4 percent during the period February 2008-February 2009, compared to 6.1 percent during the same period in the previous year.

But, surprisingly, open unemployment has not increased sigbnificantly in that period. Even, it declined between February-August 2009 (Figure 10). One explanation is that Indonesia has a large informal sector which absorbed laid-off employees from crisis-affected firms in the formal sector. In other words, the impact of the crisis on Indonesia's labour market atwas not the significant increase in open employment but in disguised unemployment working in the infomral sector. The most important policy implication from this fact is that the government must fully support the development of micro and small enterprises which are mainly found in the informal sector. The measures what these enterprises need are not only in terms of subsidized credit schames but also in marketing and production assistances, transfer of technology and other necessary knowledges, human resource improvement through reeducation or vocational training, infrastructure development, and many others.

Finally, the impact of the crisis on poverty in Indonesia was the most concern in that time. As shown before, in the aftermath of the 1997/98 crisis, poverty increased dramatically from around 17.47 per cent in 1996 to about 24.23 per cent in 1998 , when the crisis reached its climax. However, in 1999 poverty started to decline gradually, though first very slightly, up to 2005. In 2006, due to the high increase in world fuel prices, and as Indonesia has become increasingly dependent on imports of oil, the poverty rate increased again, on average between 1.8 




Figure 8. Total Number of Indonesian Overseas Workers, 2000-2008 (000 persons). (Source: Yudo et al.[7])

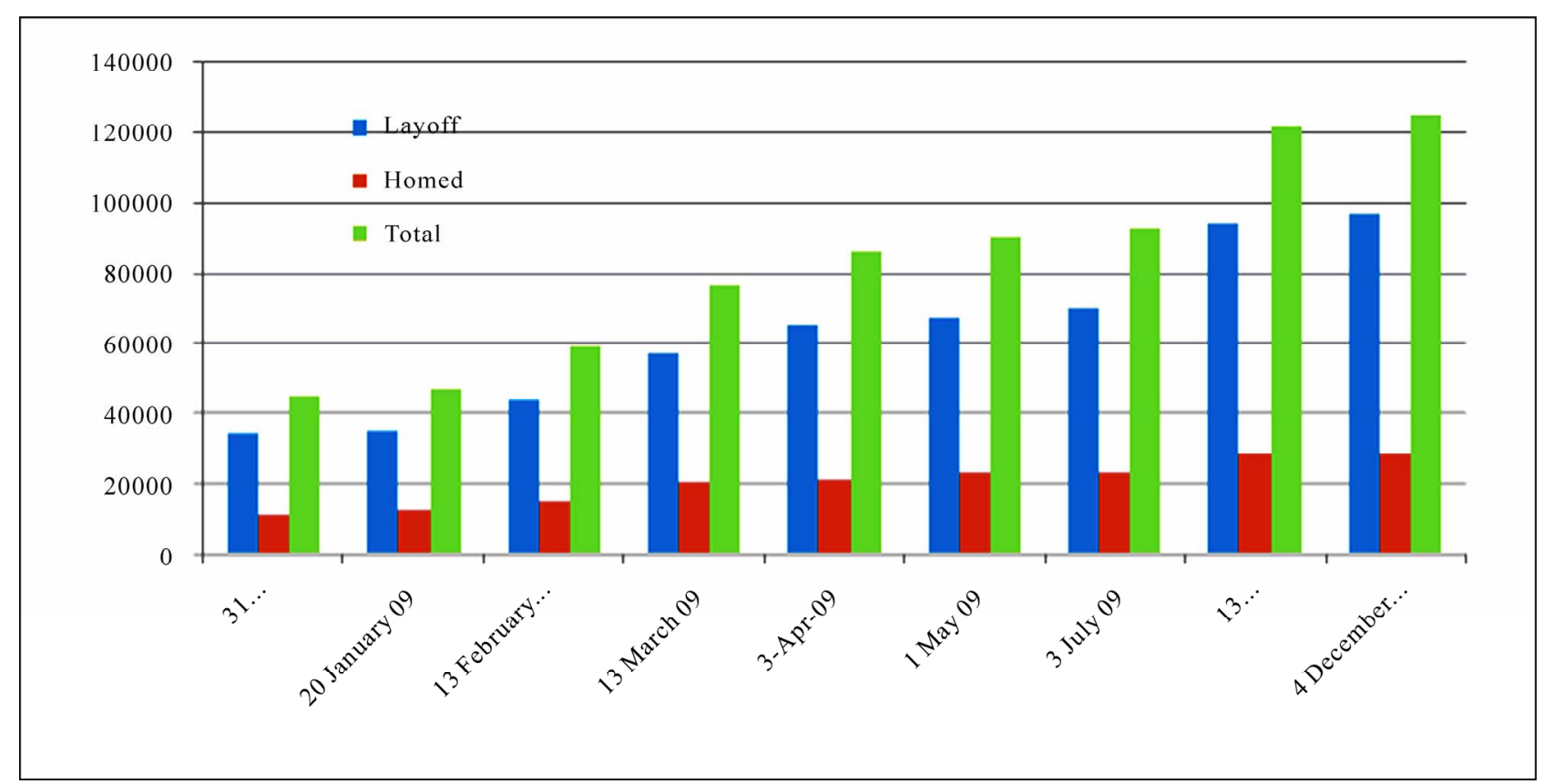

Figure 9. Number of Laid off and homed workers in the formal sector, 31 December 2008-4 December 2009. (Source: Ministry of Manpower and Transmigration, and BPS (www.bps.go.id/sakernas).)

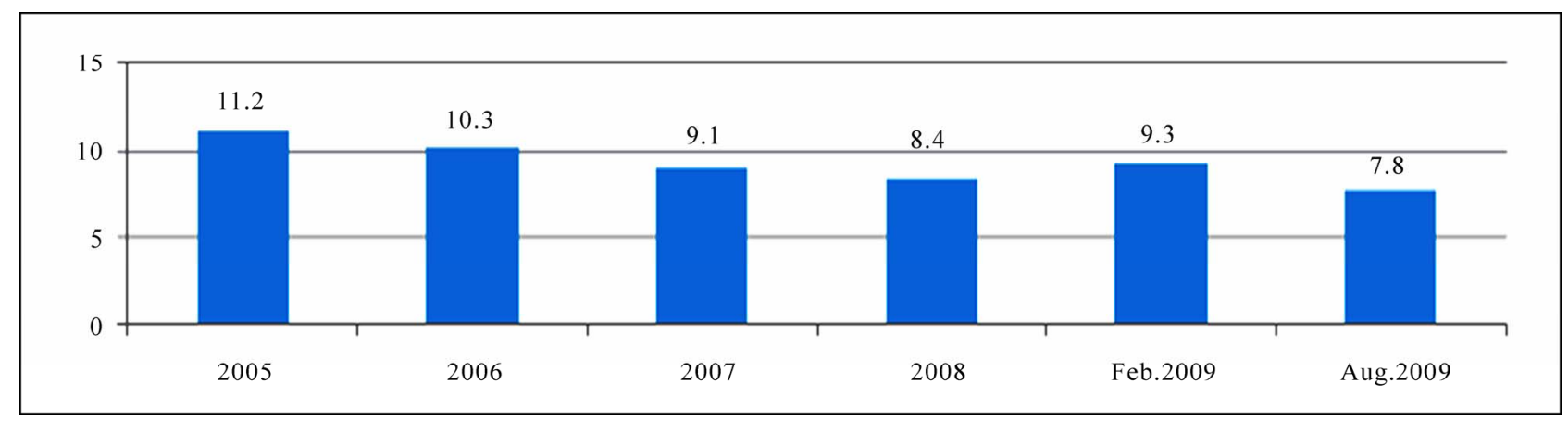

Figure 10. Open Unemployment Rate, 2005-2009 (\%). (Source: BPS (www.bps.go.id/sakernas).) 
percentage point per year or about 4.2 million people fell into poverty between the period 2005-2006. Only after some policy adjustments and macroeconomic stabilization, the poverty rate started to decline again in 2007. In relative terms, the poverty rate in 2007 was the same as that before the 1997/98 crisis. However, in absolute terms, the number of those living under the current poverty line was still higher than that in the pre-1997/98 crisis period. Although the difference varies by year, the poverty rate in urban areas is always lower than that in rural areas. According to World Bank's estimates, the poverty rate is likely to continue to fall, from 14.2 per February 2009 to around 13.5 per cent in early 2010 and 11.4 per cent in early 2011 (Table 2). This suggests that the 2008/09 crisis would not lead to an increase of the poverty rate in Indonesia (as compared to the 1997/98 crisis).

\section{Main Factors That Made the Difference}

By now it is well known that Indonesia was not only weathering the 2008/09 global economic crisis better than most other countries, but it was also much different than during the 1997/98 Asian financial crisis. The World Bank [10]concludes the following: One year after the global financial crisis and economic downturn, Indonesia's economy appears to be broadly back on track. Economic activity has been picking up, inflation has remained moderate, financial markets have risen, and the newly reelected government, having established the strong fundamentals that supported Indonesia through the global crisis, appears to be now gearing up for new investments in Indonesia's physical infrastructure, human services and institutions of state. Indonesia seems well-positioned to get back on its pre-crisis growth trajectory, with the possibility of further acceleration and more inclusive growth (page iv).

Was the difference because the Indonesian government's response this time was more quick or was better prepared than during the 1997/98 crisis, or there were other factors? According to many discussions/studies, ${ }^{2}$ there are various reasons, and the most important ones are the followings:

1) from a regional perspective, the Indonesian economy performed well in the years before 2008 (with one of the best growth rates in Asia after the 1997/98 Asian crisis up to 2008, particularly during the period 2005-2008);

2) the banking sector remains in good health (which was not the case in the years before the 1997/98 Asian economic crisis), although bank lending growth reduced in line with the slowing economy;

\footnotetext{
${ }^{2}$ See for instance, $[1,8,12-16]$.
}

3) consumer prices kept stable, allowing Bank Indonesia (BI) to loosen monetary policy (which is important to keep consumption growth);

4) Indonesia's external position remained sound, the country's significant external financing obligations are being met, and foreign exchange reserves have risen slightly;

5) Indonesia's public finances are strong (which was not the case during the 1997/98 Asian crisis), allowing policy makers to quickly move to offset the global downturn's effects on Indonesia with a fiscal stimulus;

6) also based on the experience of the $1997 / 98$ crisis, cautious policies by Indonesia's government, banks, and corporations, over the past decade have resulted in low debt levels and limited refinancing needs. This served the country especially well in late 2008 and early 2009 , when liquidity tightened around the world;

7) compared with some Asian countries, Indonesia is a relatively "closed economy"; 3

8) consumers kept spending despite the fact that banks tightened credits in late 2008. Much of this spending might also related to the election related activities; and

9) based on the experience of the $1997 / 98$ Asian crisis, this time the Indonesian government was more quick and more active in response with appropriate measures to the crisis, e.g. by providing the stimulus through fiscal and monetary policies.

While, main reasons given by the Asian Development Bank that made Indonesia was more resilience than other countries during the 2008/09 crisis are the followings [11]:

1) the impact of a spike in risk aversion was muted by steady policy responses in Indonesia and the stabilising impact of co-ordinated global counter-measures on global financial markets;

2) the income impact of the fall in commodity prices was mitigated by the fact that the preceding years had seen record high prices for these same commodities, allowing rural households to build up a savings buffer to help them smoothen out consumption spending;

3) because the global recession was of relatively short duration, the lagged effects of the financial crisis were avoided;

4) the government's good housekeeping of previous years provided it with the space to take swifter and more effective policy responses than in previous episodes of

\footnotetext{
${ }^{3}$ In his study, Djaja [15] shows that the share of Indonesia's exports to GDP was 29.4 per cent in 2007. The figure in the next three quarters of 2008 was 30.0 per cent on average. About 85 per cent of goods and services produced by Indonesian economy were used domestically in 2005 , while only about 15 per cent went to foreign buyers. This indicates that Indonesia is not so strongly integrated with the rest of the world, at least from an export point of view. With such low exports, a sudden drop in world income and hence in world demand for Indonesian exports will not affect significantly domestic production.
} 
Table 2. Poverty in Indonesia, 2000-2011.

\begin{tabular}{ccccccc}
\hline \multirow{2}{*}{ Year } & \multicolumn{3}{c}{ Number of Poor (million) } & \multicolumn{3}{c}{ Percentage of poverty (\%) } \\
\cline { 2 - 6 } & Urban & Rural & Total & Urban & Rural & Total \\
\hline 2000 & 12.30 & 26.40 & 38.70 & 14.60 & 22.38 & 19.14 \\
2001 & 8.60 & 29.30 & 37.90 & 9.76 & 24.84 & 18.41 \\
2002 & 13.30 & 25.10 & 38.40 & 14.46 & 21.10 & 18.20 \\
2003 & 12.20 & 25.10 & 37.30 & 13.57 & 20.23 & 17.42 \\
2004 & 11.40 & 24.80 & 36.10 & 12.13 & 20.11 & 16.66 \\
2005 & 12.40 & 22.70 & 35.10 & 11.68 & 19.98 & 15.97 \\
2006 & 14.49 & 24.81 & 39.30 & 13.47 & 21.81 & 17.75 \\
2007 & 13.56 & 23.61 & 37.17 & 12.52 & 20.37 & 16.58 \\
2008 & 12.77 & 22.19 & 34.96 & 11.65 & 18.93 & $15.42^{*}$ \\
2009 &.. &.. &.. &.. &.. & $14.20^{* *}$ \\
2010 &.. &.. &.. &.. &.. & $13.51^{* * *}$ \\
2011 &.. &. &.. &.. & $11.42^{* * *}$ \\
\hline
\end{tabular}

Note: *= March; $* *$ February ${ }^{* * *}$ World Bank's estimates ([10]. Source: BPS (www.bps.go.id).

external shocks; and

5) the balance sheets of the banking, corporate, and household sectors were much stronger.

\section{Concluding Remarks}

The 2008/2009 global economic crisis started first in 2007 as a financial crisis in the US and then some months latter spread worldwide. The crisis has affected many countries, including Indonesia. While many other cuntries in the region started to show a significant decaleration in their economic growth in the first quarter of 2009 , the economic growth rate in Indonesia begun to fall only in the last quarter of 2009. However Indonesia has managed to keep its economic growth rate above zero in 2009, though it was much weaker as compared to its economic growth in 2008 , or lower than the average growth since the country had recovered from the 1997/98 Asian financial crisis.

This study comes with two main important findings. First, despite many laid-off workers in the formal sector were reported, the official (open) unemployment has not increased significantly. Even, by August 2009, the rate declined compared to the level by February 2009. The most possible reason for this was that most (if not all) of the laid off employees ended up in economic activities in the informal sector, either es low-paid workers or owners of micro or small businesses. This reason is said most likely is due to the fact that Indonesia does not have a social security system as the one known in the west which provides unemployment benefits to those who have no while looking for jobs. Thus, for the laid off employees from the formal sector who were engaged in informal economic activities, they did that just as a means for them to survive. The informal sector has proved to be very important during the crisis as the last resort for them.

Second, the poverty level in Indonesia has not increased as what was happened during the 1997/98 crisis, when poverty rate increased from around 17.5 per cent in 1996 to 24.2 per cent in 1998 with the negative economic growth at around 13 per cent in 1998. Even, poverty kept decreasing during the 2008/09 crisis period. At least, two main reasons that can explain this. First, despite the crisis, Indonesia managed to keep positive economic growth in 2009 , although at a lower rate than in 2008. In other words, although many employees were laid off in the formal sector, many people still have their jobs. Second, as explained before, the informal sector has provided alternative income sources to the laid off employees, which kept them away from falling to poverty.

\section{References}

[1] ADB, “Asian Development Outlook 2010," Asian 
Development Bank, Manila, 2010a.

[2] Feridhanusetyawan, Tubagus, Haryo Aswicahyono and Titik Anas, "The Economic Crisis and the Manufacturing Industry: The Role of Industrial Networks," CSIS Working Paper Series WPE 053, January, Jakarta: Center for Strategy and International Study (CSIS), 2000.

[3] Chhibber, Ajay, Jayati Ghosh and Thangavel Palanivel, "The Global Financial Crisis and the Asia-Pacific Region. A Synthesis Study Incorporating Evidence from Country-Case Studies", UNDP Regional Center in Asia and the Pacific, Bangkok, November 2009.

[4] Ausaid, "Impact of the Asia Crisis on Children: issues for social safety nets," First report, Canberra: Australian Agency for International Development, May 1999.

[5] World Bank, "Global Economic Prospect. Crisis, Finance and Growth 2010," Washington, D.C., 2010a.

[6] ILO, Labour and Social Trends in Indonesia 2009. Recovery and beyond through Decent Work, Jakarta: International Labour Organisation Office for Indonesia, 2009.

[7] Y. Yudo, S. T. Ira and S. Hadi, "The Impact of the Global Financial Crisis on Indonesia's Economy," Study Report submitted to The United Nations Development Programme (UNDP), September, Centre for Strategic and International Studies (CSIS), Jakarta, 2009.

[8] ADB, “Asian Development Outlook 2009 Update," Asian Development Bank, Manila, 2009.

[9] ASEAN-World Bank, "ASEAN Assessment o the Social
Impacts of the Global Financial Crisis," A Snap-shot Report for notation at the 15th ASEAN Summit, Cha-am Hua Hin, Thailand, 23 October 2009.

[10] World Bank, "Migration and Development Brief 10," Washington, D.C, 13 July 2009a.

[11] ADB, "Impact and Policy Responses: Indonesia, Philippines and Thailand," Report 6, ADB Regional Forum on the Impact of Global Economic and Financial Crisis, Asian Development Bank, Manila, 14-15 January 2010 b.

[12] World Bank, "Developing Indonesia's Crisis Monitoring and Response System," Power Point Presentation, World Bank Poverty Team, Jakarta, 6 June 2009b.

[13] World Bank, "Indonesia's Crisis Monitoring and Response System (CMRS). Analysis and Presentation of CMRS Data," First Round Summary Report, Jakarta, 25 January 2010b.

[14] D. Komara, "Impact of the Global Financial and Economic Crisis on Indonesia. A Rapid Assessment," paper prepared for the ILO, Secretary Coordinating Ministry for Economic Affairs, Indonesia, 2009.

[15] M. Zavadjil, "Indonesia'S Strong Balance Sheets-Key To Weathering the Global Financial Crisis," East Asia Forum, 19 November 2009.

[16] World Bank, "Battling the forces of global recession, a World Bank Economic Update for the East Asia and Pacific Region," Bangkok, April 2009c. 


\section{Appendix}

1. From 1994/04 Indonesia start up the second 25-year long-term construction projects. Further investment restrictions to attracting foreign investment, and to take measures to support small and medium enterprises, tourism and increase exports. But in 1997 by the Southeast Asian financial crisis, significant economic recession, currency devaluation, rising inflation. In 1999 the economy began to slow recovery, but the rectification resistance greater private enterprise debt, bad debt problems difficult to solve. 2. Then, in 2008/09 global economic crisis.To keep the economic increase and make more people have their jobs is the key to solve poverty. You mention Overseas Workers and homed workers, use two Figure ( $8 \&$ 9) which analysis the conditions of the Indonesia, but no concrete solution. Make a little improvement will be perfect. 